\title{
Iran:
}

\section{Hverken brød eller frihed}

Af Ali Alfoneh

Takket være sin beliggenhed midt i et af de mest seismisk aktive områder i verden rammes Iran bestandigt af jordskælv af forskellig styrke. Det samme gælder for tilbagevendende politiske skælv. Imidlertid har Den Islamiske Republik hidtil overlevet såvel geologiske som politiske rystelser. Det sidste kan lidt forenklet tilskrives de herskende eliters selvopholdelsesdrift kombineret med oppositionens spaltning i to indbyrdes stridende hovedgrupper: De som forlanger brød, og de som forlanger frihed. Nu hvor Den Islamiske Republik hverken ønsker eller evner at levere brød eller frihed, frygter regimet dagen, hvor de sultne og de frihedselskende gør fælles front.

Protestbølgen som skyllede over Iran i december 2017 var pjalteproletariatets oprør imod de iranske ledere.

Præsident Hassan Rouhanis bebudede budgetstramninger for finansåret marts 2018 til marts 2019, som indebar fjernelse af subsidier til benzinprisen (Iran er en af verdens største olieeksportører, men importerer benzin på grund af begrænset raffinaderi-kapacitet) samt hastigt stigende fødevarepriser og nogle regionale pensions- og sparekassers fallit starte- de fredelige protester i fattige forstæder til Mashhad i det nordøstlige Iran, men spredte sig hurtigt til det meste af Iran.

I begyndelsen rettede demonstranterne skytset mod Rouhanis økonomiske politik, men inden længe forvandlede protesterne sig til politiske optøjer med slagord mod Irans gejstlige magthavere, herunder Ayatollah Ali Khamenei og Revolutionsgarden, regimets betydeligste magtorgan.

En blanding af Rouhanis løfte om ikke at røre ved subsidierne, iransk politis forholdsvis professionelle tackling af protesterne samt Revolutionsgardens bemærkelsesværdige fravær på gadeniveau for ikke yderligere at provokere offentligheden bragte optøjerne til ophør i januar.

Regimet åndede lettet op: Middelklassen, som forlanger politiske rettigheder, sluttede sig ikke til de fattige, og protesterne bredte sig aldrig til Teheran eller Tabriz.

Skælvet hørte hjemme i den lavere ende af Richterskalaen og skrev sig på listen over fattigdomsoptøjer i Den Islamiske Republiks historie.

\section{Sociale optøjer}

I kølvandet på revolutionen i 1979, konsoliderede regimet sin magt ved effektivt at undertrykke al hjemlig opposition. Den revolutionære gejst samt den nationalisti- 


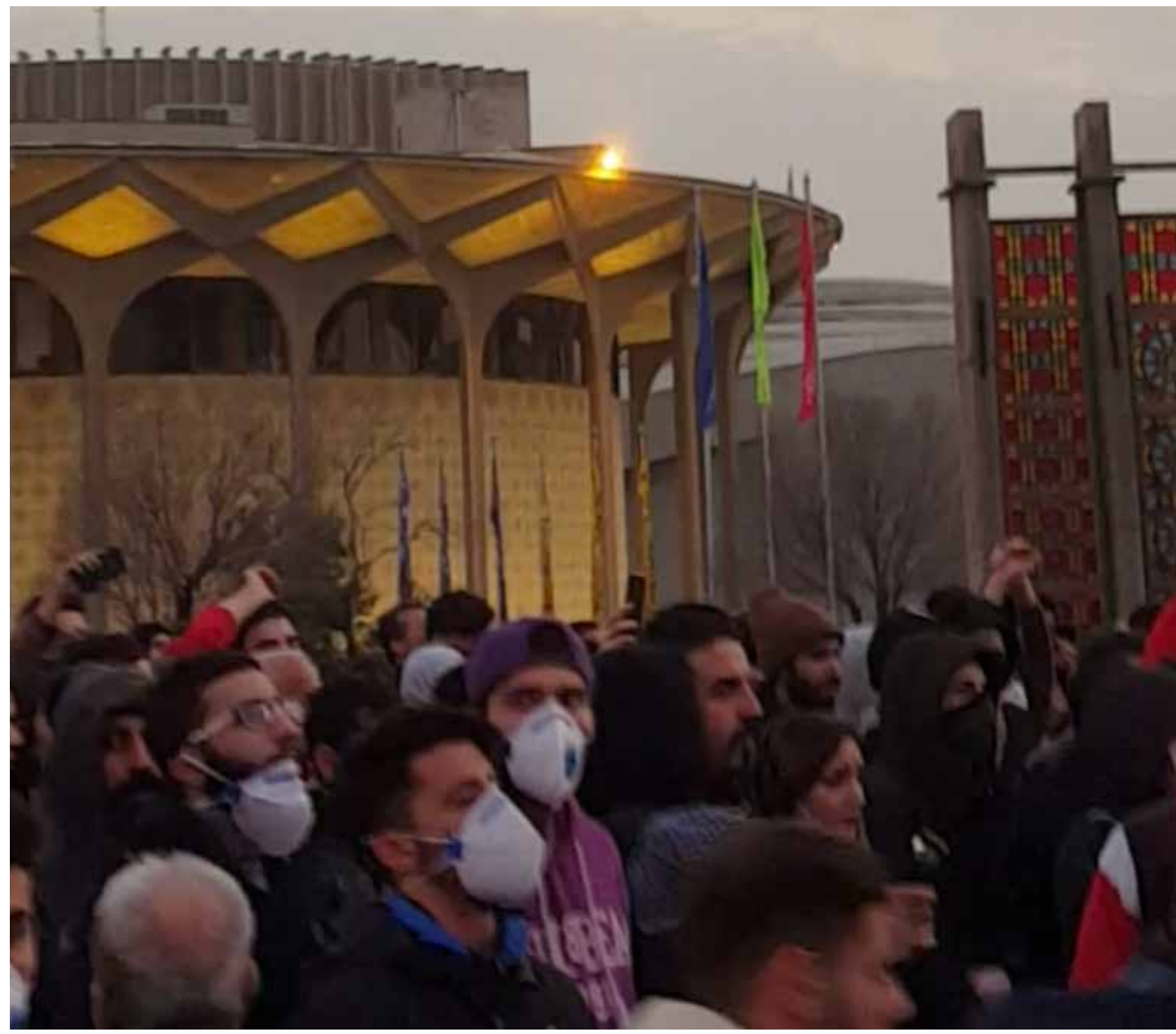

FOTO: GTVM92 via wikimedia commons

Iranere protesterer mod regeringen, Teheran 30. december 2017

ske vækkelse efter Iraks invasion af Iran i 1980 førte også til national samling. Med undtagelse af ganske få demonstrationer imod krigen hen mod krigsafslutningen i 1988 var der ingen større demonstrationer imod regimet.

Efter krigsafslutningen var stemningen en anden. Krigstidens selvopofrelse veg pladsen for stigende forventninger, og iranerne forlangte at få andel i fredsdividenden. Daværende præsident Akbar Hashemi Rafsanjani var dog mere optaget af at sikre Iran lån fra Verdensbanken. Washington Consensus var vigtigere end revolutionens løfte om social retfærdighed, og Rafsanjanis økonomiske reformer gik hårdt ud over fattige iranere, som længtes efter krigsårenes rationering af subsidierede basisfødevarer.

Optøjerne startede i maj 1992, hvor en tiårig dreng døde, da Mashhads bystyre forsøgte at jævne nogle blikskure i byens fattige forstæder med jorden. Hele nabolaget angreb den lokale politistation, afvæbnede politiet og brugte våbnene til at plyndre banker og sætte ild til offentlige bygninger i Mashhad.

Optøjerne spredte sig hurtigt til Arak i 
Markazi-provinsen, Mobarakeh i Isfahan og det fattige Chahardangeh-nabolag i det sydlige Teheran. Det var kun med nød og næppe, at Revolutionsgarden formåede at genoprette orden, og til skræk og advarsel hængte regimet anførerne i optøjerne på storbyernes centrale torve.

Sociale optøjer fortsatte i 1990'erne, og i april 1995 strejkede buschauffører i Teherans fattige Eslamshahr-forstad imod Rafsanjanis forsøg på at reducere benzinsubsidierne. Passagererne, som så deres busbilletter stige med 30 pct., sluttede sig til chaufførerne, og snart angreb 50,000 vrede syd-teheranere benzintanke og blokerede motorvejen til Teheran. Revolutionsgardens specialstyrker angreb oprørerne fra helikoptere, og 50 dræbte senere kunne regeringen genåbne motorvejene til hovedstaden.

\section{Politiske protestbølger}

Anderledes politiske var studenteroprøret i juli 1999. Den milde politiske atmosfære under præsident Mohammad Khatami havde givet iranske studerende mod på at gøre deres krav om yderligere politiske li-

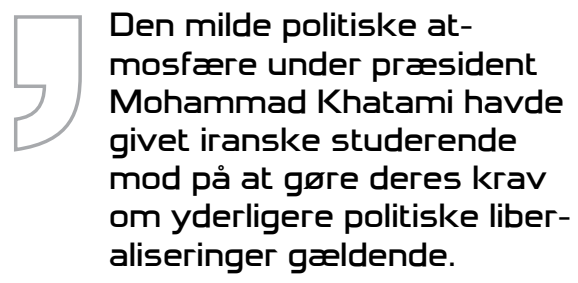

beraliseringer gældende.

Da censurmyndighederne lukkede det reformvenlige dagblad Salam, besatte de studerende Teherans Universitet og barrikaderede Meidan-e Enqelab (Revolutionstorvet). Besættelsen trak ud, men politiet fjernede de studerende, da en gruppe fremtrædende officerer fra Revolutionsgarden i et åbent brev til Khatami truede med at tage sagen i egen hånd for at 'forsvare revolutionen'

Den næste store politiske protestbølge opstod i juni 2009 fremprovokeret af præsidentvalget, som for anden gang - og mod forventning - kårede Mahmoud Ahmadinejad som republikkens præsident. Protesterne, som var en slags forløber for hvad der senere blev kendt som 'Det Arabiske Forår,' skabte Irans 'Grønne Bevægelse', som kulminerede i demonstrationer i Teheran, hvor en million iranere gik på gaden imod valgsvindel.

Bevægelsen var måske nok anført af de økonomisk bedrestillede borgere i Teheran og andre storbyer, men mange fattige sluttede sig til protesterne. Det var kun med nød og næppe at Revolutionsgarden og Basij-militsen formåede at undertrykke optøjerne.

\section{Strukturelle problemer}

I sammenligning med 2009, udgjorde december 2018-protesterne næppe nogen større trussel mod regimets overlevelse, men de viser samtidig tre strukturelle problemer i det iranske politiske system:

For det første er Den Islamiske Republiks herskende eliter ved at positionere sig for at øve indflydelse på arvefølgen efter Ayatollah Ali Khamenei. Eliterne kan lidt forsimplet inddeles i regimets to søjler: Teknokraterne anført af Rouhani og Revolutionsgarden, som beskytter regimet mod den hjemlige opposition og afskrækker eksterne fjender.

I deres indbyrdes rivalisering forsøger de også at mobilisere befolkningen for deres sag blandt andet ved at angribe hinandens økonomiske interesser. Rouhani forsøger at fravriste Revolutionsgarden dens økonomiske interesser (mere end en tredjedel af de børsnoterede virksomheder på Teherans Børs ejes af Revolutions- 
gardens mange finans- og kreditinstitutter, og gardens ingeniørkorps er samtidigt landets største entreprenørvirksomhed), mens Revolutionsgarden anklager Rouhani for at have svigtet de fattige og sågar for at have været med til at puste til protesternes ild i december 2018. I fald protesterne udvikler en effektiv ledelse, kan de spille på rivaliseringen mellem teknokraterne og Revolutionsgarden.

For det andet overstiger Den Islamiske Republiks regionale ambitioner landets begrænsede økonomiske formån. December måneds optøjer var præget af slagord imod Revolutionsgardens militære engagement i Syrien og Irak, og overalt råbte folk 'Hverken Gaza eller Lebanon, jeg ofrer mit liv for Iran' eller 'Lad Syrien være, tænk på os'!

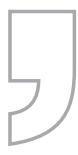

\section{Protesterne, som var en slags forløber for hvad der senere blev kendt som 'Det Arabiske Forår', skabte Irans 'Grønne Bevægelse', som kulminerede i demon- strationer i Teheran, hvor en million iranere gik på gaden imod valgsvindel.}

Iran finansierer sine regionale militære eventyr ved hjælp af indtægterne fra olieeksporten, som til gengæld er genstand for store udsving på grund af svingningerne i olieprisen.

Irans støtte til Bashar al-Assads regime i Syrien er et godt eksempel herpå. Teheran menes at understøtte Damaskus med mellem 15 til 20 mia. dollar. Den Islamiske Republiks årlige økonomiske støtte til Islamisk Hamas er begrænset til nogle hundreder mio. dollar, mens støtten til libanesisk Hizbollah anslås at være på ca. en mia. dollar. Organisationens generalsekretær anerkendte den iranske støtte i juni 2016 ved at påpege: "Hizbollahs budget, lønninger, mad, drikke og våben kommer alle fra Iran... Så længe Iran har penge, har vi også!"

Til sammenligning var Rouhanis budgetforslag til finansåret 2018/19 på blot 103 mia. Ifølge Centralbankens beregninger har det indeværende finansårs budget et underskud på over 5,3 mia. dollar, hvilket forklarer Rouhanis forsøg på at skære ned på subsidierne til benzinprisen i næste års budget.

Med andre ord, står Teheran over for det lidet misundelsesværdige valg mellem enten at sænke sine regionale ambitioner og mindske støtten til sine allierede for at brødføde sin egen befolkning eller lade befolkningen sulte i et forsøg på at sikre sin position som regional hegemon. På længere sigt bringer denne ubalance mellem storpolitiske ambitioner og hjemlige behov regimets overlevelse i fare.

For det tredje tyder en række tegn på, at den veluddannede middelklasse og de underprivilegerede kunne finde sammen. I kølvandet på fattigdomsoptøjerne er der opstået en kvindebevægelse imod den påtvungne islamiske hijab, som mobiliserer kvinderne i storbyerne. Adskilte udgør de, som forlanger brød, og de, som forlanger frihed - herunder friheden til ikke at lade sig dække af påtvungen hijab - næppe nogen større udfordring mod Den Islamiske Republik, men tilsammen udgør de en formidabel trussel mod regimets overlevelse.

Alt imens må regimets herskende eliter overveje, om de ønsker eller ser sig i stand til at enten at levere brød eller frihed. 